\title{
BUDAYA MELABUH SEBAGAI KEARIFAN LOKAL MASYARAKAT BANTARAN SUNGAI KOTA BANJARMASIN UNTUK MEMENUHI HAJAT
}

\begin{tabular}{|c|}
\hline Muhammad Azhari Mutaqin \\
\hline $1910128210020 @$ mhs.ulm.ac.id \\
Program Studi Pendidikan IPS FKIP, Universitas Lambung Mangkurat \\
\hline
\end{tabular}

\begin{abstract}
This article aims to describe the culture of harboring as local wisdom for the riverbank community of Banjarmasin City. In this study, the author uses a qualitative method by conducting a literature study based on the problems discussed, namely the Culture of Harboring as Local Wisdom for the Riverside Communities of Banjarmasin City. The results of this study show that some of the people of Banjar believe and establish the culture of harboring is a culture that is intended for those who want to have the intention that they carry out the culture of anchoring by drifting according to the river. The ancestors are believed to be able to help, and disturb the families of the porters. From that belief, they give offerings in the form offood, drinks, flowers, and others that are put into the river water, so that the ancestors do not disturb them and can help them. This harboring activity is usually carried out by the people of Banjarmasin City on the banks of the river which has become a habit of their parents for generations, which makes this harboring culture always passed down from generation to generation.
\end{abstract}

\section{Keywords: Culture, Melabuh, Riverside Communities}

\begin{abstract}
ABSTRAK
Artikel ini memiliki tujuan untuk memaparkan budaya melabuh sebagai kearifan lokal masyarkat bantaran sungai Kota Banjarmasin. Pada penelitian ini penulis menggunakan metode kualitatif dengan melakukan studi pustaka berdasarkan permasalahan yang dibahas yakni Budaya Melabuh Sebagai Kearifan Lokal Masyarakat Bantaran Sungai Kota Banjarmasin. Pada hasil penelitian ini menampilkan bahwa sebagian masyarakat Banjar mempercayai dan menjalin budaya melabuh adalah budaya yang diperuntukan untuk mereka yang ingin memiliki hajat agar mereka melakukan budaya melabuh dengan cara menghanyutkan sesuai ke sungai. Para leluhur dipercaya dapat membantu, dan mengganggu keluarga para pelabuh. Dari kepercayaan itu, mereka memberi sesajen berupa makanan, minuman, kembang, dan lainnya yang dimasukan ke dalam air sungai, agar para leluhur tidak mengganggu dan dapat membantu mereka. Kegiatan melabuh ini biasanya dilakukan oleh masyarakat Kota Banjarmasin di bantaran sungai yang sudah menjadi kebiasaan orang tua mereka selama turun temurun yang menjadikan budaya Melabuh ini selalu diwariskan dari generasi ke generasi.
\end{abstract}

\section{Kata kunci: Budaya, Melabuh, Masyarakat Bantaran Sungai}




\section{PENDAHULUAN}

Budaya merupakan sebuah kebiasaan yang dilakukan terus berulang dengan didasari unsur kebudayaan (Subiyakto, 2020). Adapun kearifan lokal terbentuk dari dua kata yaitu kearifan (wisdom) dan lokal (local). Pada Kamus Inggris-Indonesia John M. Echols dan Hassan Shadily, local berarti 'setempat', sedangkan wisdom adalah 'kebijaksanaan'. Jadi kearifan lokal juga dapat diartikan sebagai pengetahuan lokal yang sudah sedemikian menyatu dengan sistem kepercayaan, norma, budaya, serta diekspresikan dalam tradisi dan mitos yang dianut dalam jangka waktu yang lama. Kearifan lokal mengacu pada nilai-nilai dalam masyarakat dan menjaga keseimbangan alam (Subiyakto, 2020).

Satu dari beberapa kearifan lokal yang masih berlangsung sampai saat ini adalah kearifan lokal yang terdapat pada masyarakat Banjar. Pada beberapa daerah di bantaran sungai Kota Banjarmasin terdapat berbagai kearifan lokal dalam bentuk aturan-aturan serta tradisi yang telah turun temurun. Masyarakat bantaran sungai adalah kelompok masyarakat yang bermukin di tepian sungai yang menjadikan sungai sebagai sumber kehidupan (Jumriani, 2021). Beragam aktivitas yang dilakukan di sungai yakni antara lain menjadikan sungai sebagai tempat untuk bekerja, memanfaatkan sumber daya alam yang berasal dari sungai seperti air sungai dan ikan sungai yang bisa dijual serta dijadikan lauk untuk makan sehari-hari (Putro, 2020).

Sebagian masyarakat Banjar yang masih melakukan kegiatan kebudayaan juga masih memegang teguh mitos-mitos dari leluhurnya (Nadhiroh, 2020). Tidak hanya dalam bentuk aturan masyarakat, mereka juga masih melaksanakan tradisi yang ada baik berupa kebudayaan maupun upacara adat. Satu dari bentuk kebudayaan yang akan dibahas penulis yakni budaya Melabuh yang ada pada masyarkat Banjar yang bertujuan untuk memenuni sebuah hajat seorang pelabuh tersebut. Melabuh adalah budaya berupa menghayutkan beberapa makanan dan benda ke sungai, biasanya mereka melakukan hal tersebut pada saat ingin meminta kelancaran acara yang akan dilakukan dihari selanjutnya.

Dari pembahasan yang ada di atas, penulis memiliki ketertarikan untuk membahas lebih lanjut mengenai kearifan lokal tersebut sebab hingga saat ini masih ada beberapa orang yang melakukan budaya tersebut serta budaya tersebut saat ini sangat menjadi pro 
dan kontra banyak masyarakat karena dinilai bertentangan dengan ajaran Islam, sebab sebagian besar masyarkat Banjar beragama islam (Aslan, 2020). Adapun tujuan dari artikel ini yaitu untuk lebih mengetahui tentang budaya Melabuh yang dilakukan masyarakat bantaran sungai serta kekurangan dan kelebihan dari kearifan lokal tersebut. Untuk mengetahui hal tersebut, penulis melakukan studi literatur dari berbagai sumber seperti jurnal ilmiah, buku, artikel, dan sebagainya.

\section{HASIL DAN PEMBAHASAN}

Kearifan lokal adalah identitas atau kepribadian budaya sebuah bangsa yang menyebabkan bangsa tersebut mampu menyerap, bahkan mengolah kebudayaan yang berasal dari luar/bangsa lai menjadi watak dan kemampuan sendiri. Identitas dan Kepribadian tersebut tentunya menyesuaikan dengan pandangan hidup masyarakat sekitar agar tidak terjadi pergesaran nilai-nilai. Kearifan lokal adalah salah satu sarana dalam mengolah kebudayaan dan mempertahankan diri dari kebudayaan asing yang tidak baik. Kearifan lokal adalah pandangan hidup dan ilmu pengetahuan serta berbagai strategi kehidupan yang berwujud aktivitas yang dilakukan oleh masyarakat lokal dalam menjawab berbagai masalah dalam pemenuhan kebutuhan mereka. Dalam bahasa asing sering juga dikonsepsikan sebagai kebijakan setempat local wisdom atau pengetahuan setempat "local knowledge" atau kecerdasan setempat local genious. Berbagai strategi dilakukan oleh masyarakat setempat untuk menjaga kebudayaannya.

Suyakto (2020) menyatakan bentuk-bentuk kearifan lokal adalah bentuk kepercayaan beragaman dalam wujud praktik sosial yang dilandasi suatu kearifan dari budaya. Bentuk-bentuk kearifan lokal dalam masyarakat dapat berupa budaya (nilai, norma, etika, kepercayaan, adat istiadat, hukum adat, dan aturan-aturan khusus). Nilainilai luhur terkait kearifan lokal meliputi Cinta kepada Tuhan, alam semester beserta isinya,Tanggung jawab, disiplin, dan mandiri, Jujur, Hormat dan santun, Kasih sayang dan peduli, Percaya diri, kreatif, kerja keras, dan pantang menyerah, Keadilan dan kepemimpinan, Baik dan rendah hati,Toleransi,cinta damai, dan persatuan.

Hal hampir serupa dikemukakan oleh Nadhiroh (2019) kearifan lokal merupakan tata aturan tak tertulis yang menjadi acuan masyarakat yang meliputi seluruh aspek kehidupan, berupa Tata aturan yang menyangkut hubungan antar sesama manusia, 
misalnya dalam interaksi sosial baik antar individu maupun kelompok, yang berkaitan dengan hirarkhi dalam kepemerintahan dan adat, aturan perkawinan antar klan, tata karma dalam kehidupan sehari-hari.

Masyarakat bantaran sungai adalah masyarakat yang bermukin di tepian sungai yang menjadikan sungai sebagai sumber berkehidupan sehari-hari (Subiyako, 2020). Adapun fungsi sungai bukan hanya sebagai sumber kehidupan, khususnya pada masyarakat Banjar menjadikan sungai sebagai tempat untuk melangsungkan prosesi kebudayaan (Jumriani, 2021). Jauh sebelum adanya perkembangan globalisasi, masyarakat Banjar memiliki banyak sekali kebudayaan yang berkaitan dengan sistem kepercayaan dengan hal ghaib satu diantaranya budaya Melabuh urang Banjar. Banyak yang berfikir hal ini bertentangan dengan agama Islam, akan tetapi Sebagian masyarakat percaya bahwa dengan melakukan ritual ini, mereka bisa meminta sesuatu atau menginginkan hajat. Masyarakat Banjar adalah masyarakat religious yang menjadikan agama sebagai sumber nilai dalam kehidupan sehari-hari (Handy, 2020). Meskipun masyarakat Banjar religious dan identik dengan Islam, namun dalam kehidupan seharihari masih ditemukan kepercayaan dan perilaku yang bukan bersumber dari Islam, seperti kepercayaan dan perilaku mereka terhadap para leluhur (Subiyakto, 2020).

Budaya Melabuh merupakan budaya menghanyutkan sebuah bentuk sesajen ke sungai dengan berbagai macam tujuan dan keinginan. Sebagian orang percaya bahwa dengan menghanyutkan sesajen ke sungai mereka memberi makan "Datu" atau yang sering kita ketahui yakni para leluhur. Pemberian sesajen kepada Datu sebagai tanda ingin meminta hajat biasanya dilakukan sekali dalam setahun atau lebih. Bila ada indikasi yang dirasakan oleh yang bersangkutan seperti sakit yang tak kunjung sembuh atau memiliki hajat yang sangat besar, maka hal ini dipahami sebagai isyarat tiba saatnya untuk malabuh. Meski demikian, bisa pula pemberian sesajen itu dilakukan tanpa harus didahului oleh isyarat tersebut, tetapi diberikan bila diperkirakan sudah tiba waktunya.

Adapun sesajen itu terdiri dari 1 biji telor ayam masak, nasi ketan (dimasak dari beras ketan 0,5 liter atau sampai 1 liter) dimasukkan dalam piring, pisang dan kembang; semuanya dimasukan dalam kantungan plastik; nama yang bersangkutan ditulis di kertas bersama nama orang tuanya. Kemudian waktu malabuh (meletakkan, melepas) sesajen itu biasanya dilakukan pada senja hari (malam Jumat) atau bisa juga senja malam Senin. 
Pada senja hari lain tidak dianjurkan, sebab buaya-buaya itu diyakini tidak ada ditempat yang kita inginkan. Kemudian sesajen itu biasanya diletakkan di tengah arus air sungai; atau bisa pula di laut bila kebetulan tidak ada sungai. Peletakkan sesajen bisa dilakukan oleh kita sendiri atau dipercayakan kepada orang lain, yang penting dia punya keberanian dan mengerti tata caranya.

Adapun tempat menaruh atau meletakkan sesajen itu tidak sembarang tempat, tidak boleh di darat melainkan harus di air seperti sungai kecil atau besar dan sesajen itu sebaiknya dilabuh (dilepas, ditaruh) di tengah arus sungai. Pemilihan tempat untuk melepas sesajen tersebut di sungai sebagai pertanda bahwa kehidupan leluhur pada zaman dulu itu pada umumnya adalah di air bukan di darat. Sebelum malabuh (melepas) sesajen, terlebih dahulu memberi salam kepada datu kemudian disebutkan nama dan bin siapa yang memberikan sesajen itu. Biasanya pada saat malabuh ada terasa sesuatu kekuatan yang menarik seperti magnit ke dalam air. Ini sebagai pertanda kehadiran datu tersebut, dan pada saat itu sesajen segera dilepas sebab kalau tidak dapat berakibat ikut tercebur ke dalam air (Subiyakto, 2005).

Adapun para sebagian masyarakat Banjar Melabuh pada kesempatan lain, seperti melakukan sesajen yang dilakukan setahun sekali tepatnya setiap tanggal 1 Muharram, tidak boleh terlewat karena dikawatirkan dapat berakibat yang tidak baik. Kemudian yang memberikan sesajen itu adalah yang bersangkutan (yang kena pingit) langsung, kecuali bagi yang tidak mengerti tata caranya atau tidak berani melakukannya sendiri. Dalam kondisi seperti ini boleh saja dipercayakan kepada orang lain yang mengerti tata caranya. Selain pemberian sesajen secara berkala setiap tahunnya, dalam acara-acara lain seperti selamatan perkawinan, kenduri ataupun acara selamatan lainnya, juga disiapkan sesajen untuk para leluhur. Sesajennya berupa makanan yang diambil sekedarnya dari setiap jenis menu makanan yang akan disuguhkan kepada tamu undangan dalam cara tersebut sebelum makanan itu dicicipi. Tujuannya adalah agar acara itu tidak terganggu dan berjalan dengan lancar sesuai dengan yang diharapkan.

Semua hal yang dilakukan untuk sebuah keinginan yang diharapkan terkabul, akan tetapi pada beberapa kasus yang melakukan budaya Melabuh secara rutin harus tetap melakukan budaya Melabuh tanpa terkecuali sesuai dengan waktu yang sudah di tetapkan. Jika tidak dilakukan akan berdampak buruk. Gangguan yang dialami bisa 
bermacam-macam. Hal ini muncul bila tidak Melabuh akan mengalami sesuatu yang dikawatirkan misalnya berupa gangguan saat acara perkawinan seperti mempelainya jatuh pingsan tanpa sebab yang diketahui, perut seperti orang hamil, lemah fisik bahkan bisa mengalami kelumpuhan, gatal-gatal, yang tidak kunjung sembuh walaupun ada upaya berobat secara medis, namun setelah dilakukan pemberian sesajen, berbagai keluhan dapat teratasi. (dalam logat Banjar diistilahkan dengan seperti membuang kalimpanan). Pengalaman seperti ini melahirkan kepercayaan kuat bagi masyarakat Banjar tentang adanya hubungan dengan para leluhur. Selanjutnya bermacam gangguan tersebut tidak akan terulang bilamana pemberian sesajen diperhatikan setiap tahun.

Adapun proses kebudayaan melabuh terjadi sebab adanya sejarah panjang perjalanan agama-agama seperti Animisme, Dinamisme, Hindu, Budha dan beberapa kepercayaan lokal pernah berkembang masih meninggalkan bekas kepada orang Melayu yang notabene adalah muslim (Abbas, 2017). Kepercayaan dan perilaku terhadap hubungan para leluhur adalah refleksi dari sejarah panjang agama-agama tersebut. Masyarakat Banjar adalah masyarakat tradisionalis yang cenderung menerima tradisi dan budaya yang diwariskan turun temurun (Subiyakto, 2020). Adanya kepercayaan, perilaku dan kebiasaan masyarakat bantaran sungai Kota Banjarmasin terhadap budaya Melabuh. Namun yang membedakan tidak ada pengakuan mereka menyebutkan bahwa yang diberikan sesajen itu merupakan leluhur atau nenek moyang mereka.

\section{SIMPULAN}

Sebagian masyarakat Banjar mempercayai dan meyakini bahwa jika mereka memiliki hajat, maka mereka bisa melakukan ritual atau budaya Melabuh. Hubungan tersebut dilestarikan merupakan hasil warisan dari nenek moyangnya yang harus diterima. Sebab bila terjadi penolakan, para leluhur akan marah dan menganggu juriat anak cucu pelabuh. Namun bila warisan leluhur ini diterima maka kehidupan yang dilajarinya akan lancar. Dengan adanya anggapan atau kepercayaan dan keyakinan terhadap para leluhur, sehingga sebagian masyarakat Banjar memberi sesajen berupa nasi ketan, telor, pisang dan lain-lain yang di masukan ke dalam air sungai. Perilaku sebagian masyarakat ini secara tutun-temurun. Hal ini dilakukan dengan harapan para leluhur tidak mengganggu dan membantu juriat atau anak cucu orang yang melabuh. 


\section{DAFTAR PUSTAKA}

Abbas, E. W. (2017). Pendidikan Sejarah, Patriotisme \& Karakter Bangsa MalaysiaIndonesia.

Aslan, A., Suhari, S., Antoni, A., Mauludin, M. A., \& MR, G. N. K. (2020). Dinamika Keagamaan Masyarakat Perbatasan Paloh Kabupaten Sambas, Kalimantan Barat. Jurnal Antropologi: Isu-Isu Sosial Budaya, 22(1), 90-101.

Basrian, B., Maimanah, M., \& Arni, A. (2014). Kepercayaan dan Perilaku Masyarakat Banjar dalam Hubungan Kekerabatan dengan Buaya Jelmaan di Banjarmasin dan Banjarbaru. Tashwir, Jurnal Penelitian Agama dan Sosial Budaya, 1(2).

Handy, M. R. N., Mutiani, M., Putra, M. A. H., \& Jumriani, J. (2020). The Religious Values in Tradition of Batahlil in Banjar Pahuluan Community. The Kalimantan Social Studies Journal, 2(1), 39-47.

Jumriani, J., Mutiani, M., Putra, M. A. H., Syaharuddin, S., \& Abbas, E. W. (2021). The Urgency of Local Wisdom Content in Social Studies Learning: Literature Review. The Innovation of Social Studies Journal, 2(2), 103-109.

Jumriani, J., Ilmiyannor, M., \& Mi'rajiatinnor, D. (2021, February). Strengthening Environmental Care Attitudes Through Social Wisdom-Based Social Studies Learning. In The 2nd International Conference on Social Sciences Education (ICSSE 2020) (pp. 65-69). Atlantis Press.

Nadhiroh, W. (2019). NALAR KEBERAGAMAAN MASYARAKAT BANJAR: DARI MISTIS-REALIS HINGGA TRADISIONALIS-KRITIS. Al-Banjari: Jurnal Ilmiah Ilmu-Ilmu Keislaman, 18(2), 246-273.

Putro, H. P. N., \& Jumriani, J. (2020). KEHIDUPAN SOSIAL DAN EKONOMI MASYARAKAT BANTARAN SUNGAI SEBAGAI SUMBER BELAJAR IPS. Banjarmasin: Pendidikan IPS FKIP ULM.

Subiyakto, B. (2005). Totemisme, Mitos Bagaduhan Buhaya Pada Masyarakat Banjar. dalam Kandil, Edisi, 9.

Subiyakto, B. (2005). Menjadikan Sungai Sebagai Objek Studi. Jurnal Kandil Edisi Tahun III Mei-Juli. 
Subiyakto, B., Abbas, E. W., Arisanty, D., Mutiani, M., \& Akmal, H. (2020). Sungai dan Kehidupan Masyarakat Banjar: Penguatan Lokalitas dalam Wacana Pendidikan IPS yang Responsif.

Subiyakto, B., Mutiani, M., Faisal, M., \& Mutaqin, M. A. (2020). Social Interaction of Jukung Craftsmen in Pulau Sewangi, Alalak, Barito Kuala. The Innovation of Social Studies Journal, 1(2), 102-110.

Subiyakto, B., Sari, N. P., Mutiani, M., Faisal, M., \& Rusli, R. (2020). Bonding Social Capital in Social Activities of Urang Banjar in the Martapura Riverbank. The Innovation of Social Studies Journal, 2(1), 17-24. 